\title{
The Kidney-Associated Microbiome of Wild-Caught Artibeus spp. in Grenada, West Indies
}

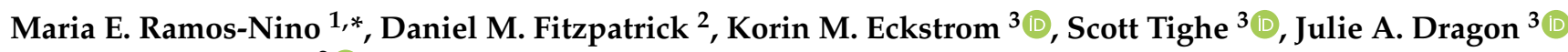 \\ and Sonia Cheetham ${ }^{2}$ (D) \\ 1 Department of Microbiology, Immunology, and Pharmacology, School of Medicine, St. George's University, \\ West Indies, Grenada \\ 2 Department of Pathobiology, School of Veterinary Medicine, St. George's University, West Indies, Grenada; \\ dfitzpat@sgu.edu (D.M.F.); scheetha@sgu.edu (S.C.) \\ 3 Larner School of Medicine, University of Vermont Massively Parallel Sequencing Facility, \\ Burlington, VT 05401, USA; korin.eckstrom@med.uvm.edu (K.M.E.); scott.tighe@uvm.edu (S.T.); \\ julie.dragon@med.uvm.edu (J.A.D.) \\ * Correspondence: maramosni@sgu.edu; Tel.: +1-802-8936358
}

check for updates

Citation: Ramos-Nino, M.E.; Fitzpatrick, D.M.; Eckstrom, K.M.; Tighe, S.; Dragon, J.A.; Cheetham, S. The Kidney-Associated Microbiome of Wild-Caught Artibeus spp. in Grenada, West Indies. Animals 2021, 11, 1571. https://doi.org/10.3390/ ani11061571

Academic Editor: Valentina Virginia Ebani

Received: 27 April 2021

Accepted: 24 May 2021

Published: 27 May 2021

Publisher's Note: MDPI stays neutral with regard to jurisdictional claims in published maps and institutional affiliations.

Copyright: (c) 2021 by the authors. Licensee MDPI, Basel, Switzerland. This article is an open access article distributed under the terms and conditions of the Creative Commons Attribution (CC BY) license (https:// creativecommons.org/licenses/by/ $4.0 /)$.
Simple Summary: Bats are increasingly being recognized as important integrants of zoonotic disease cycles. Studying bat microbiomes could potentially contribute to the epidemiology of emerging infectious diseases in humans. Furthermore, studying the bat's microbiome gives us the opportunity to look at the microbiome evolution in mammals. Bat microbiome studies have focused mainly on the gut microbiome, but little is known of the microbiome of the kidney, another potential source of disease transmission. Furthermore, many studies on microbiome found in the literature are based on captive animals, which usually alters the natural microbiome. Here, we analyzed kidney samples of wild-caught Artibeus spp., a fructivorous bat species from Grenada, West Indies, using metagenomics.

Abstract: Bats are capable of asymptomatically carrying a diverse number of microorganisms, including human pathogens, due to their unique immune system. Because of the close contact between bats and humans, there is a possibility for interspecies transmission and consequential disease outbreaks. Herein, high-throughput sequencing was used to determine the kidney-associated microbiome of a bat species abundant in Grenada, West Indies, Artibeus spp. Results indicate that the kidney of these bats can carry potential human pathogens. An endogenous retrovirus, Desmodus rotundus endogenous retrovirus isolate 824 , phylogenetically related to betaretroviruses from rodents and New World primates, was also identified.

Keywords: Artibeus; bats; betaretrovirus; kidney; metagenomics

\section{Introduction}

The microbiome is a key element of life. It is associated with the immune system and defense against pathogens [1-3], energy processing [4,5], behavior [6], mating [7-9], and evolution [10], among other aspects. Many studies on microbiome found in the literature are based on captive animals, which usually alters the natural microbiome. Studies on wild animals are needed to establish key players in the microbiome and determine how it affects the potential host for disease transmission and its capacity as a reservoir [10].

Bats (order Chiroptera, suborders Megachiroptera and Microchiroptera), encompassing 17 families and $>1200$ species, are the second-largest mammalian group in the world [11-13]. Bats' lifestyle, including food choices, population structure, movement patterns, life span, and roosting behaviors, make them accessible to many pathogens [12,14]. However, what makes them a potential reservoir of human pathogens and other animals is the specialized immune system that allows them to carry pathogens without being affected themselves. The evolution of bats may have selected a unique set of antimicrobial immune responses that control microbial propagation while limiting self-damaging 
inflammatory responses [15-17]. Among the microorganisms detected in healthy bats are filoviruses, paramyxoviruses, and coronaviruses that cause severe diseases, such as Ebola virus disease, Marburg hemorrhagic fever, and severe acute respiratory syndrome (SARS), in humans [13,18-22]. The increasing rate of bat-associated infections is supported by an increasing overlap between bat and human habitats [21]. The Database of Bat-associated uses (DBatVir) (http: / /www.mgc.ac.cn/DBatVir (accessed on 1 May 2020)) provides updates on the virome diversity of bats, as well as ecological and epidemiological data to track bat-related transmissible diseases.

Bats play an important role in many ecosystems [23-25], but little is known about their microbiome and how it impacts the health and behavior of the bats in different regions. Bat-associated disease outbreaks in humans (e.g., Nipah, Hendra, SARS-Cov1, SARS-Cov2, and Ebola) have, however, stimulated research on microbiome dynamics in bats [12,26,27]. Some examples of metagenomes of bats have appeared in the literature [13,27-31], but more research is needed at the local level and with a specific focus on particular mechanisms to determine their potential involvement in pathogen transmission.

Published studies on the microbiota of bats have focused on capture and euthanasia or capture and release of bats. They have used urine and fecal samples directly collected in hand from the animal [32-36]. Other studies have focused on the use of gut tissue or feces for the analysis of the microbiome in bats, and few studies have used urine samples for this analysis as well; however, to our knowledge, no study has focused on kidney's microbiota for this analysis. In this study, we analyzed kidney samples of the Artibeus spp. population, a fructivorous bat species, from Grenada, West Indies.

\section{Materials and Methods}

Neotropical bats were trapped on the island of Grenada, West Indies, from 2015 to 2017 using mist nets, hand nets, and a harp trap. Live capture, along with proper monitoring of traps and nets, ensured animal safety as recommended by the Animal Care and Use Committee of the American Society of Mammalogists [37]. Bats ( $n=173)$ of the most abundant species were collected from coastal areas around the island where the majority of the human population is located. Due to the changing taxonomic status of bats in the Artibeus jamaicensis complex of bats and the difficulty of classifying the Artibeus genus by morphology alone, all potential Artibeus jamaicensis, Artibeus planirostris, and Artibeus schwartzi bats in this study were collectively identified as Artibeus spp. Bats were identified morphologically [38] and confirmed by cytochrome B PCR [39] as Artibeus spp.

\subsection{Bat Processing}

Live bats were transported to the necropsy laboratory at St. George's University, School of Veterinary Medicine (SGU SVM), Grenada, West Indies, in individual opaque cloth bags to prevent post-capture cross-contamination. Bats were euthanized in the necropsy lab using isoflurane followed by thoracotomy and cardiac exsanguination while under anesthesia. Tissue samples were stored in RNAlater at $-20{ }^{\circ} \mathrm{C}$ and formalin.

\subsection{Histopathology}

Bat kidney tissues were fixed by immersion in 10\% neutral buffered formalin, embedded in paraffin, sectioned at $4 \mu \mathrm{m}$, stained with hematoxylin and eosin (HE) and Warthin-Starry (WS) silver stain (kidneys only) using standard histological techniques, and examined by light microscopy (Nikon LV100, Microscopecentral, Feasterville, PA, USA) by a board-certified veterinary pathologist as previously described [40].

\subsection{Total RNA Extraction and RNA-Seq}

RNA was extracted from $30 \mathrm{mg}$ of kidney tissue from two randomly selected bats after tissue disruption in a bead-beater (Mini Beadbeater Biospec Products, Bartlesville, OK, USA) using TRIzol (Life Technologies Cat\#15596-018). Invitrogen ${ }^{\mathrm{TM}}$ Phasemaker $^{\mathrm{TM}}$ Tubes (ThermoFisher Scientific Cat\#A33248) were used for phase separation. RNA was DNase- 
treated using TURBO DNA-free ${ }^{\mathrm{TM}}$ (Life Technologies Cat\#AM1907, Durham, NC, USA), and RNA quality was evaluated using a Bioanalyzer (Agilent 2100, Agilent Technologies. Inc, Santa Clara, CA, USA) as previously described [41].

Libraries for shotgun metagenomic and meta-transcriptomic sequencing were pooled and run on a single lane of an Illumina HiSeq 2500 (Illumina, San Diego, CA, USA) Quality of raw reads was assessed using FastQC version 0.11.8; the reads were then trimmed using Trim Galore (v 0.6.4) (https:/ /www.bioinformatics.babraham.ac.uk/projects/trim_galore/ (accessed on 1 May 2020)) to remove Illumina universal adaptors, bases with a quality score $<20$, and reads shorter than $35 \mathrm{bp}$. Trimmed reads were mapped to the A. jamaicencis reference genome (https:/ / www.ncbi.nlm.nih.gov/genome/12026?genome_assembly_id=4379 54 (accessed on 1 May 2020)) using KneadData (v0.7.4) (https://huttenhower.sph.harvard. edu/kneaddata/). Reads mapping to the host was removed from further analysis, leaving 2-4 million reads per sample. Taxonomic classification was performed using Kraken2 ( https://genomebiology.biomedcentral.com/articles/10.1186/s13059-019-1891-0 (accessed on 1 May 2020)) with the microbial database compiled by the Loman Lab available online (https:/ /lomanlab.github.io/mockcommunity/mc_databases.html (accessed on 1 May 2020)). This database includes all complete and representative genomes available in RefSeq for archaea, bacteria, fungi, protozoa, viral, and UniVec_Core sequences. In addition to this, viral sequences were profiled using FastViromeExplorer (https:/ / peerj.com/articles/4227/ (accessed on 1 May 2020)) against the NCBI DNA, RNA, and eukaryotic viral databases available at FastViromeExplorer (https:/ / bench.cs.vt.edu/FastViromeExplorer/ (accessed on 1 May 2020)). Estimated abundance is expressed as total read counts adjusted for the segment size of detected viruses (Figure 1).

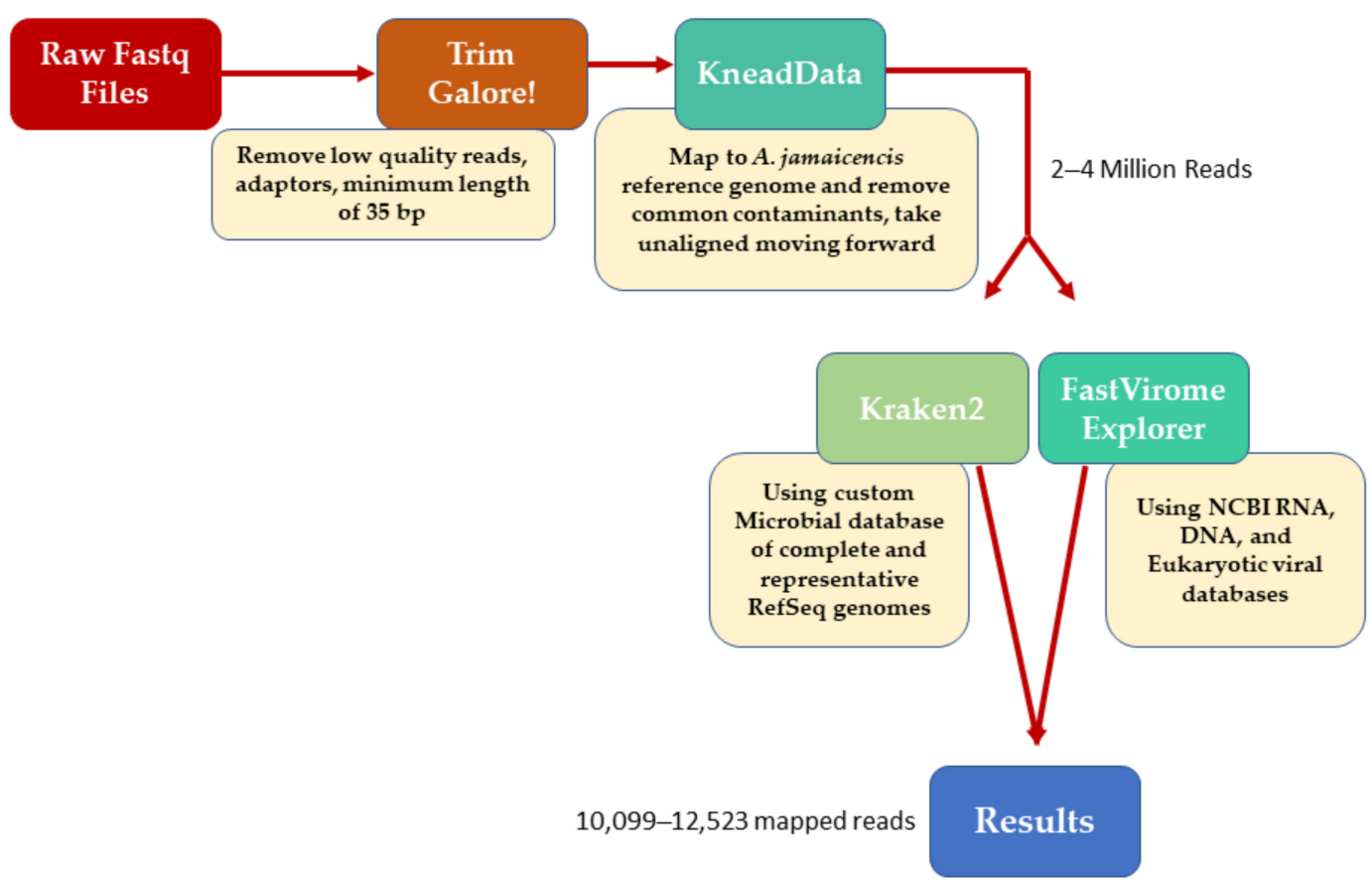

Figure 1. Metagenomic data analysis flow chart.

For further confirmation of results, reads matching at the genus level were filtered from the dataset and assembled using SPAdes (v3.14.0) (accessed on 2 May 2020) [42] with the parameters $-\mathrm{k} 21,33,55,77,99,127$, and with the coverage cutoff disabled due to the low abundance of certain taxa. The resulting contigs were then identified using BLASTn (Table 1). All raw data are available under the BioProject accession PRJNA638959 (https://www.ncbi.nlm.nih.gov/sra/PRJNA638959). 
Table 1. Resulting contigs identified using BLASTn.

\begin{tabular}{ccc}
\hline Organism & Sample \#1 & Sample \#2 \\
\hline Bacteria & 8174 & 6675 \\
Fungi & 4100 & 3083 \\
Viruses & 249 & 241 \\
\hline
\end{tabular}

\section{Results}

Histopathological and postmortem examination of the bats' kidneys suggested that the bats used in this study were healthy and showed adequate body condition, mild to moderate parasite burden, and no lesions that suggest significant overt disease within the examined organ system as described previously by us [40].

The resulting contigs identified using BLASTn are presented in Table 1. The metagenomic analysis of two kidney samples is presented in Table 2.

Table 2. Kidney-associated microbiota in Artebius spp. from Grenada, West Indies, expressed as relative estimated abundance (REA).

\begin{tabular}{|c|c|c|c|c|c|c|}
\hline Organism & & & & & Sample \#1 & Sample \#2 \\
\hline & Phylum & Class & Family & Genus & & \\
\hline \multirow[t]{7}{*}{ Bacteria } & & & & & 65.27 & 66.09 \\
\hline & Proteobacteria & $\begin{array}{c}\text { Gammaproteo- } \\
\text { bacteria }\end{array}$ & Enterobacteriaceae & Escherichia & 51.22 & 49.01 \\
\hline & Spirochaetes & Spirochaetia & Leptospiraceae & Leptospira & 12.82 & 15.24 \\
\hline & Actinobacteria & Actinobacteria & Micrococcaceae & Nesterenkonia & 0.11 & 0.11 \\
\hline & Actinobacteria & Actinobacteria & Dietziaceae & Dietzia & 0.10 & 0.11 \\
\hline & Proteobacteria & Betaproteobacteria & Comamonadaceae & Acidovorax & 0.09 & 0.08 \\
\hline & Firmicutes & Clostridia & Clostridiaceae & Clostridium & 0.01 & 0.2 \\
\hline \multirow[t]{3}{*}{ Fungi } & & & & & 32.74 & 30.53 \\
\hline & & Oomycetes & Peronosporaceae & Plasmopara & 31.36 & 30.00 \\
\hline & Ascomycota & Eurotiomycetes & Aspergillaceae & Aspergillus & 0.34 & 0.42 \\
\hline Viruses & & & Retroviridae & Betaretrovirus * & 1.99 & 3.38 \\
\hline
\end{tabular}

${ }^{*}$ Endogenous retrovirus isolate 824 .

\section{Discussion}

The microbiota found in this study, as indicated in Table 1, such as Escherichia coli, have rarely been mentioned in the literature in association with bats. Nowak et al. [43] investigated the presence of $E$. coli in the liver, lung, and intestine of tissues collected from 50 fruit bats of five different species (no Artibeus included) in the Republic of Congo. Herein, E. coli was detected in $60 \%$ of the bats analyzed. Although the majority of strains were assigned to phylogenetic group B2 (46.2\%), which is linked with the ExPEC pathovar, the occurrence of virulence-associated genes in these strains was unexpectedly low, suggesting a lack of contact with humans or domestic animals. Future studies will be needed to characterize the kidney-associated E. coli population of Artibeus in Grenada, West Indies.

Results here and in a previous publication by our team [40] suggest that bats in Grenada, West Indies, can act as renal carriers, and this is particularly important for the epidemiology of organisms of certain specific genera, such as Leptospira. Leptospires colonize the renal tubules of the carrier animals and are then shed intermittently with urine. Human infection usually results from contact with this urine or from environmental sources that have been contaminated with it [44].

Species of the genus Nesterenkonia have been isolated from different ecological niches, particularly from saline habitats, and have been reported as weak human pathogens that cause asymptomatic bacteremia [45]. Most reports are associated with gut microflora, including that of Vaziri et al. [46], which reported an increased abundance of Nesterenkonia 
in the feces of patients with end-stage renal disease. No report of the presence of this organism in bats has been published to date.

The genus Dietzia, usually mistaken for Rhodococcus, has only been established recently as a separate genus. Currently, there is available evidence on the clinical significance of Dietzia species in the context of their potential role as human pathogens [47]. The evidence suggests there is a medical significance in the members of the genus Dietzia. Most of these organisms have been isolated from environmental samples, and the characterization of Dietzia in bats will help shed some light on these animals as potential reservoirs.

Acidovorax spp. similar to the fungi Plasmopara, are usually considered plant pathogens, and infections in humans are rare [48,49]. The presence of these organisms is probably associated with feeding habits.

Bats usually inhabit shelters with conditions favorable for fungal proliferation, including pathogenic and opportunistic species [50]. However, little is known about the fungal diversity present in bats. Herein, we found Aspergillus in the kidney samples. Kidneys are the most predominantly involved part of the urinary tract in invasive aspergillosis because these organisms primarily affect the lungs; however, all bats in this study were clinically healthy. The fact that Aspergillus was found in all samples suggests the role of bats as a carrier. Further studies will be needed to establish if this is the case.

No significant reads of viruses were found in our kidney samples, except Desmodus rotundus endogenous retrovirus isolate 824 , as determined by the read assembly, which has been indicated in the Methods section. Desmodus rotundus endogenous betaretrovirus (DrERV) is present in the vampire bat $D$. rotundus population and in other phyllostomid bats; however, it is not present in all member species of this family [51,52]. DrERV is not phylogenetically related to Old World bat betaretroviruses but rather to betaretroviruses from rodents and New World primates, suggesting recent cross-species transmission [51]. Retroviruses are abundant in bats, and it is likely that they represent at least in part genomic contaminants and should therefore not directly be linked to a zoonotic potential [53].

\section{Conclusions}

The kidneys of bats are potential reservoirs for the transmission of pathogenic organisms. The fact that these organisms are in the kidneys of clinically healthy bats indicates that these animals can tolerate their presence in what should be a sterile organ. The importance of these findings in bats in the context of disease transmission is to be determined; however, some of the agents we found in these samples can be pathogenic to humans.

Another important finding of this study was the presence of a retrovirus identified in the vampire bat; however, the implication in terms of phylogenetic evolution is still to be determined.

Author Contributions: Conceptualization, M.E.R.-N. and S.C.; Data curation, K.M.E. and S.T.; Formal analysis, M.E.R.-N. and K.M.E.; Funding acquisition, M.E.R.-N. and S.C.; Methodology, M.E.R.-N., D.M.F., and S.C.; Project administration, M.E.R.-N.; Resources, S.C.; Supervision, M.E.R.-N. and J.A.D.; Writing—original draft, M.E.R.-N.; Writing—review and editing, S.C. All authors have read and agreed to the published version of the manuscript.

Funding: This research was funded by the Windward Islands Research and Education Foundation's One Health Research Initiative Grant 04-11-10.

Institutional Review Board Statement: Protocols for trapping, handling, and euthanizing bats were approved by the Institutional Animal Care and Use Committee (IACUC-14008-R) at St. George's University, School of Veterinary Medicine, and consent from the Grenada Ministry of Agriculture, Forestry, Wildlife and Fisheries, Grenada, West Indies, was obtained for the same. Bats were trapped using mist nets and hand nets. Both of these methods are approved as humane by the Animal Care and Use Committee of the American Society of Mammologists [37].

Data Availability Statement: All raw data are available under the BioProject accession PRJNA638959 (https:/ / www.ncbi.nlm.nih.gov/sra/PRJNA638959). 
Acknowledgments: Thanks to the Grenada Ministry of Agriculture, Fisheries and Wildlife for granting permission to trap bats. Special thanks to Amber Lee, Marcy Kanuka, and Veronica MappAlexander for their contribution to the capture and processing of the bats.

Conflicts of Interest: The authors declare no conflict of interest.

\section{References}

1. Chung, H.; Pamp, S.J.; Hill, J.A.; Surana, N.K.; Edelman, S.M.; Troy, E.B.; Reading, N.C.; Villablanca, E.J.; Wang, S.; Mora, J.R.; et al. Gut immune maturation depends on colonization with a host-specific microbiota. Cell 2012, 149, 1578-1593. [CrossRef]

2. Mazmanian, S.K.; Liu, C.H.; Tzianabos, A.O.; Kasper, D.L. An Immunomodulatory Molecule of Symbiotic Bacteria Directs Maturation of the Host Immune System. Cell 2005, 122, 107-118. [CrossRef] [PubMed]

3. Shekhar, S.; Petersen, F.C. The dark side of antibiotics: Adverse effects on the infant immune defense against infection. Front. Pediatr. 2020, 8, 544460. [CrossRef] [PubMed]

4. Turnbaugh, P.J.; Ley, R.E.; Mahowald, M.A.; Magrini, V.; Mardis, E.R.; Gordon, J.I. An obesity-associated gut microbiome with increased capacity for energy harvest. Nat. Cell Biol. 2006, 444, 1027-1031. [CrossRef] [PubMed]

5. Bäckhed, F.; Ley, R.E.; Sonnenburg, J.L.; Peterson, D.A.; Gordon, J.I. Host-bacterial mutualism in the human intestine. Science 2005, 307, 1915-1920. [CrossRef] [PubMed]

6. Dinan, T.G.; Stilling, R.M.; Stanton, C.; Cryan, J.F. Collective unconscious: How gut microbes shape human behavior. J. Psychiatr. Res. 2015, 63, 1-9. [CrossRef] [PubMed]

7. Sharon, G.; Segal, D.; Ringo, J.M.; Hefetz, A.; Zilber-Rosenberg, I.; Rosenberg, E. Commensal bacteria play a role in mating preference of Drosophila melanogaster. Proc. Natl. Acad. Sci. USA 2010, 107, 20051-20056. [CrossRef]

8. Sharon, G.; Segal, D.; Zilber-Rosenberg, I.; Rosenberg, E. Symbiotic bacteria are responsible for diet-induced mating preference in Drosophila melanogaster, providing support for the hologenome concept of evolution. Gut Microbes 2011, 2, 190-192. [CrossRef]

9. Brucker, R.M.; Bordenstein, S.R. The hologenomic basis of speciation: Gut bacteria cause hybrid lethality in the genus Nasonia. Science 2013, 341, 667-669. [CrossRef]

10. Hird, S.M. Evolutionary biology needs wild microbiomes. Front. Microbiol. 2017, 8, 725. [CrossRef]

11. Solari, S.; Baker, R.J. Mammal species of the world: A taxonomic and geographic reference. J. Mammal. 2007, 88, 824-830. [CrossRef]

12. Calisher, C.H.; Childs, J.E.; Field, H.E.; Holmes, K.V.; Schountz, T. Bats: Important reservoir hosts of emerging viruses. Clin. Microbiol. Rev. 2006, 19, 531-545. [CrossRef]

13. He, B.; Li, Z.; Yang, F.; Zheng, J.; Feng, Y.; Guo, H.; Li, Y.; Wang, Y.; Su, N.; Zhang, F.; et al. Virome profiling of bats from myanmar by metagenomic analysis of tissue samples reveals more novel mammalian viruses. PLoS ONE 2013, 8, e61950. [CrossRef]

14. Serra-Cobo, J.; López-Roig, M. Bats and emerging infections: An ecological and virological puzzle. In Advances in Experimental Medicine and Biology; Springer: New York, NY, USA, 2017; pp. 35-48. Available online: https:// pubmed.ncbi.nlm.nih.gov/277260 73 (accessed on 21 May 2021).

15. Banerjee, A.; Baker, M.L.; Kulcsar, K.; Misra, V.; Plowright, R.; Mossman, K. Novel insights into immune systems of bats. Front. Immunol. 2020, 11, 26. [CrossRef]

16. Subudhi, S.; Rapin, N.; Misra, V. Immune system modulation and viral persistence in bats: Understanding viral spillover. Viruses 2019, 11, 192. [CrossRef]

17. Omatsu, T.; Watanabe, S.; Akashi, H.; Yoshikawa, Y. Biological characters of bats in relation to natural reservoir of emerging viruses. Comp. Immunol. Microbiol. Infect. Dis. 2007, 30, 357-374. [CrossRef] [PubMed]

18. Pourrut, X.; Souris, M.; Towner, J.S.; Rollin, P.E.; Nichol, S.T.; Gonzalez, J.-P.; Leroy, E. Large serological survey showing cocirculation of Ebola and Marburg viruses in Gabonese bat populations, and a high seroprevalence of both viruses in Rousettus aegyptiacus. BMC Infect. Dis. 2009, 9, 159. [CrossRef]

19. Li, W.; Shi, Z.; Yu, M.; Ren, W.; Smith, C.; Epstein, J.H.; Wang, H.; Crameri, G.; Hu, Z.; Zhang, H.; et al. Bats are natural reservoirs of SARS-like coronaviruses. Science 2005, 310, 676-679. [CrossRef]

20. Wang, L.F.; Shi, Z.; Zhang, S.; Field, H.; Daszak, P.; Eaton, B.T. Review of bats and SARS. Emerg. Infect. Dis. 2006, 12, 1834-1840. [CrossRef]

21. Allocati, N.; Petrucci, A.G.; Di Giovanni, P.; Masulli, M.; Di Ilio, C.; De Laurenzi, V. Bat-man disease transmission: Zoonotic pathogens from wildlife reservoirs to human populations. Cell Death Discov. 2016, 2, 16048. [CrossRef]

22. Geldenhuys, M.; Weyer, J.; Nel, L.H.; Markotter, W. Coronaviruses in South African bats. Vector-Borne Zoonotic Dis. 2013, 13, 516-519. [CrossRef] [PubMed]

23. Kasso, M.; Balakrishnan, M. Ecological and economic importance of bats (order chiroptera). ISRN Biodivers. 2013, 2013, 1-9. [CrossRef]

24. Boyles, J.G.; Cryan, P.M.; McCracken, G.F.; Kunz, T.H. Economic importance of bats in agriculture. Science 2011, $332,41-42$. [CrossRef] [PubMed]

25. Ducummon, S.L. Ecological and Economic Importance of Bats; Bat Conservation International, Inc.: Austin, TX, USA, 2001.

26. Marí Saéz, A.; Weiss, S.; Nowak, K.; Lapeyre, V.; Zimmermann, F.; Düx, A.; Kühl, H.S.; Kaba, M.; Regnaut, S.; Merkel, K.; et al. Investigating the zoonotic origin of the West African Ebola epidemic. EMBO Mol. Med. 2015, 7, 17-23. [CrossRef] 
27. Donaldson, E.F.; Haskew, A.N.; Gates, J.E.; Huynh, J.; Moore, C.J.; Frieman, M.B. Metagenomic analysis of the viromes of three North American bat species: Viral diversity among different bat species that share a common habitat. J. Virol. 2010, 84, 13004-13018. [CrossRef]

28. Li, L.; Victoria, J.G.; Wang, C.; Jones, M.; Fellers, G.M.; Kunz, T.H.; Delwart, E. Bat guano virome: Predominance of dietary viruses from insects and plants plus novel mammalian viruses. J. Virol. 2010, 84, 6955-6965. [CrossRef]

29. Zheng, X.Y.; Qiu, M.; Guan, W.J.; Li, J.M.; Chen, S.W.; Cheng, M.J.; Huo, S.T.; Chen, Z.; Wu, Y.; Jiang, L.N.; et al. Viral metagenomics of six bat species in close contact with humans in southern China. Arch. Virol. 2018, 163, 73-88. [CrossRef]

30. Yang, F.; Wang, Y.; Zheng, W.; He, B.; Jiang, T.; Li, Y.; Xia, L.; Feng, Y.; Fan, Q.; Tu, C. Metagenomic analysis of bat virome in several Chinese regions. Shengwu Gongcheng Xuebao/Chin. J. Biotechnol. 2013, 29, 586-600.

31. Dacheux, L.; Cervantes-Gonzalez, M.; Guigon, G.; Thiberge, J.M.; Vandenbogaert, M.; Maufrais, C.; Caro, V.; Bourhy, H. A preliminary study of viral metagenomics of french bat species in contact with humans: Identification of new mammalian viruses. PLoS ONE 2014, 9, e87194. [CrossRef]

32. Avena, C.V.; Parfrey, L.W.; Leff, J.W.; Archer, H.M.; Frick, W.F.; Langwig, K.E.; Kilpatrick, A.M.; Powers, K.E.; Foster, J.T.; McKenzie, V.J. Deconstructing the bat skin microbiome: Influences of the host and the environment. Front. Microbiol. 2016, 7, 1753. [CrossRef]

33. Vengust, M.; Knapic, T.; Weese, J.S. The fecal bacterial microbiota of bats; Slovenia. PLoS ONE 2018, 13, e0196728. [CrossRef] [PubMed]

34. Dietrich, M.; Kearney, T.; Seamark, E.C.J.; Paweska, J.T.; Markotter, W. Synchronized shift of oral, faecal and urinary microbiotas in bats and natural infection dynamics during seasonal reproduction. R. Soc. Open Sci. 2018, 5, 180041. [CrossRef] [PubMed]

35. Fofanov, V.Y.; Furstenau, T.N.; Sanchez, D.; Hepp, C.M.; Cocking, J.; Sobek, C.; Pagel, N.; Walker, F.; Chambers, C.L. Guano exposed: Impact of aerobic conditions on bat fecal microbiota. Ecol. Evol. 2018, 8, 5563-5574. [CrossRef] [PubMed]

36. Carrillo-Araujo, M.; Tas, N.; Alcántara-Hernández, R.J.; Gaona, O.; Schondube, J.E.; Medellín, R.A.; Jansson, J.K.; Falkón, L.I. Phyllostomid bat microbiome composition is associated to host phylogeny and feeding strategies. Front. Microbiol. 2015. [CrossRef] [PubMed]

37. Sikes, R.S.; Gannon, W.L. Guidelines of the American Society of mammalogists for the use of wild mammals in research. J. Mammal. 2011, 97, 663-688. [CrossRef] [PubMed]

38. Lim, B.K. Book reviews: Bats of Trinidad and Tobago: A field guide and natural History. Acta Chiropterologica 2015, 17, 199-200. [CrossRef]

39. Larsen, P.A.; Hoofer, S.R.; Bozeman, M.C.; Pedersen, S.C.; Genoways, H.H.; Phillips, C.J.; Pumo, D.E.; Baker, R.J. Phylogenetics and phylogeography of the Artibeus jamaicensis complex based on cytochrome-b DNA sequences. J. Mammal. 2007, 88, 712-727. [CrossRef]

40. Bevans, A.I.; Fitzpatrick, D.M.; Stone, D.M.; Butler, B.P.; Smith, M.P.; Cheetham, S. Phylogenetic relationships and diversity of bat-associated leptospira and the histopathological evaluation of these infections in bats from Grenada, West Indies. PLoS Negl. Trop Dis. 2020, 14, e0007940. [CrossRef]

41. Ramos-Nino, M.E.; Fitzpatrick, D.M.; Tighe, S.; Eckstrom, K.M.; Hattaway, L.M.; Hsueh, A.N.; Stone, D.M.; Dragon, J.; Cheetham, S. High prevalence of Phasi Charoen-like virus from wild-caught Aedes aegypti in Grenada, W.I. As revealed by metagenomic analysis. PLoS ONE 2020, 15, e0227998. [CrossRef]

42. Bankevich, A.; Nurk, S.; Antipov, D.; Gurevich, A.A.; Dvorkin, M.; Kulikov, A.S.; Lesin, V.M.; Nikolenko, S.I.; Pham, S.; Prjibelski, A.D.; et al. SPAdes: A new genome assembly algorithm and its applications to single-cell sequencing. J. Comput. Biol. 2012, 19, 455-477. [CrossRef]

43. Nowak, K.; Fahr, J.; Weber, N.; Lübke-Becker, A.; Semmler, T.; Weiss, S.; Mombouli, J.-V.; Wieler, L.H.; Guenther, S.; Leendertz, F.H.; et al. Highly diverse and antimicrobial susceptible Escherichia coli display a naïve bacterial population in fruit bats from the Republic of Congo. PLoS ONE 2017, 12, e0178146. [CrossRef] [PubMed]

44. Tulsiani, S.M.; Graham, G.C.; Dohnt, M.F.; Burns, M.; Craig, S.B. Maximizing the chances of detecting pathogenic leptospires in mammals: The evaluation of field samples and a multi-sample-per-mammal, multi-test approach. Ann. Trop. Med. Parasitol. 2011, 105, 145-162. [CrossRef] [PubMed]

45. Chander, A.M.; Nair, R.G.; Kaur, G.; Kochhar, R.; Dhawan, D.K.; Bhadada, S.K.; Mayilraj, S. Genome Insight and Comparative Pathogenomic Analysis of Nesterenkonia jeotgali Strain CD08_7 Isolated from Duodenal Mucosa of Celiac Disease Patient. Front. Microbiol. 2017, 8, 129. [CrossRef] [PubMed]

46. Vaziri, N.D.; Wong, J.; Pahl, M.; Piceno, Y.M.; Yuan, J.; DeSantis, T.Z.; Ni, Z.; Nguyen, T.-H.; Andersen, G.L. Chronic kidney disease alters intestinal microbial flora. Kidney Int. 2013, 83, 308-315. [CrossRef] [PubMed]

47. Koerner, R.J.; Goodfellow, M.; Jones, A.L. The genusDietzia: A new home for some known and emerging opportunist pathogens. FEMS Immunol. Med. Microbiol. 2009, 55, 296-305. [CrossRef]

48. Long, S.S.; Pickering, L.K.; Prober, C.G. Principles and Practice of Pediatric Infectious Diseases, 4th ed.; Elsevier: Amsterdam, The Netherlands, 2012.

49. Gessler, C.; Pertot, I.; Perazzolli, M. Plasmopara viticola: A review of knowledge on downy mildew of grapevine and effective disease management. Phytopathol. Mediterr. 2011, 50, 3-44.

50. Furtado, B.G.; Savi, G.D.; Angioletto, E.; Carvalho, F. Filamentous fungi occurrence on Molossus molossus (Pallas, 1766) (Chiroptera: Molossidae) present in an Atlantic Forest remnant in Southern Brazil. Braz. J. Biol. 2020, 81, 1073-1080. [CrossRef] 
51. Escalera-Zamudio, M.; Mendoza, M.L.Z.; Heeger, F.; Loza-Rubio, E.; Rojas-Anaya, E.; Méndez-Ojeda, M.L.; Taboada, B.; Mazzoni, C.J.; Arias, C.F.; Greenwood, A.D. A novel endogenous betaretrovirus in the common vampire bat (desmodus rotundus) suggests multiple independent infection and cross-species transmission events. J. Virol. 2015, 89, 5180-5184. [CrossRef]

52. Filho, L.C.F.; Barata, R.R.; Cardoso, J.F.; de Vasconcelos Massafra, J.M.; da Silva Lemos, P.; Casseb, L.M.N.; Cruz, A.C.R.; Nunes, M.R.T. Complete endogenous retrovirus genome sequence from a Brazilian vampire bat (desmodus rotundus). Microbiol. Resour. Announc. 2019, 8, e01497-e01518. [CrossRef]

53. Hayward, J.A.; Tachedjian, M.; Cui, J.; Field, H.; Holmes, E.C.; Wang, L.F.; Tachedjian, G. Identification of diverse full-length endogenous betaretroviruses in megabats and microbats. Retrovirology 2013, 10, 35. [CrossRef] 